\title{
Stable isotopes in cave ice suggest summer temperatures in east-central Europe are linked to Atlantic Multidecadal Oscillation variability
}

\author{
Carmen-Andreea Bădăluţăă ${ }^{1,2,3}$, Aurel Perșoiu ${ }^{1,4}$, Monica Ionita ${ }^{5}$, and Natalia Piotrowska ${ }^{6}$ \\ ${ }^{1}$ Stable Isotope Laboratory, Ştefan cel Mare University, Suceava, 720229, Romania \\ ${ }^{2}$ Department of Geography, Ştefan cel Mare University, Suceava, 720229, Romania \\ ${ }^{3}$ Institute for Geological and Geochemical Research, Research Centre for Astronomy and Earth Sciences MTA, \\ Budapest, 1112, Hungary \\ ${ }^{4}$ Emil Racoviţă Institute of Speleology, Romanian Academy, Cluj-Napoca, 400006, Romania \\ ${ }^{5}$ Alfred Wegener Institute, Helmholtz Center for Polar and Marine Research, Bremerhaven, 27515, Germany \\ ${ }^{6}$ Institute of Physics, Silesian University of Technology, Gliwice, 44-100, Poland
}

Correspondence: Carmen-Andreea Bădăluţă (carmen.badaluta@usm.ro) and Aurel Perșoiu (aurel.persoiu@gmail.com)

Received: 22 November 2019 - Discussion started: 13 January 2020

Revised: 20 October 2020 - Accepted: 28 October 2020 - Published: 10 December 2020

\begin{abstract}
The climate of east-central Europe (ECE) is the result of a combination of influences originating in the wider North Atlantic realm, the Mediterranean Sea, and the western Asian and Siberian regions. Previous studies have shown that the complex interplay between the large-scale atmospheric patterns across the region results in strongly dissimilar summer and winter conditions on timescales ranging from decades to millennia. To put these into a wider context, longterm climate reconstructions are required, but, largely due to historical reasons, these are lacking in ECE. We address these issues by presenting a high-resolution, radiocarbondated record of summer temperature variations during the last millennium in ECE, based on stable isotope analysis of a $4.84 \mathrm{~m}$ long ice core extracted from Focul Viu Ice Cave (Western Carpathians, Romania). Comparisons with both instrumental and proxy-based data indicate that the stable isotope composition of cave ice records the changes in summer air temperature and has a similar temporal evolution to that of the Atlantic Multidecadal Oscillation on decadal to multidecadal timescales, suggesting that changes in the North Atlantic are transferred, likely via atmospheric processes towards the wider Northern Hemisphere. On centennial timescales, the data show little summer temperature differences between the Medieval Warm Period (MWP) and the Little Ice Age (LIA) in eastern Europe. These findings are
\end{abstract}

contrary to those that show a marked contrast between the two periods in terms of both winter and annual air temperatures, suggesting that cooling during the LIA was primarily the result of wintertime climatic changes.

\section{Introduction}

Rapid global warming (IPCC, 2018) and the ensuing suite of climatic changes that it triggers (Coumou and Rahmstorf, 2012) demands a clear understanding of the background mechanisms in order to be able to disentangle natural and anthropogenic processes (Haustein et al., 2017; IPCC, 2018). Especially important are high-resolution reconstructions of the past variability of different climatic variables, such as seasonal air temperatures, precipitation amounts and moisture sources, that allow for direct comparisons with the dynamics of natural forcing and further decipherment of the mechanisms of past and present climate dynamics. The last 1000 years are particularly significant, as the European climate has generally changed from warm to cold (the Medieval Warm Period-Little Ice Age transition; Jones et al., 2009) and back to warm (the present-day warming; Neukom et al., 2019). These transitions allow for the links between forcing and climatic response to be tested. While several global (Jones and Mann, 2004; Mann et al., 2009) and hemispheric 
(Moberg et al., 2005; Neukom et al., 2019; PAGES 2k Consortium, 2019; Ljungqvist et al., 2019) climatic reconstructions have been published, these made no seasonal differentiation - a task that became recently increasingly necessary to constrain seasonally distinctive climatic changes (e.g., Ljungqvist et al., 2019), as these respond to different forcing mechanisms (e.g., Perșoiu et al., 2019). On multidecadal timescales, the summer climate over Europe is mainly influenced by the Atlantic Multidecadal Oscillation, or AMO (Schlesinger et al., 1994; Kaplan et al., 1998; Kerr, 2000; Knudsen et al., 2011, 2014). The AMO is a climate mode of variability associated with periodic anomalies in sea surface temperatures (SSTs) in northern, extra-tropical latitudes. The positive phase is characterized by positive SST anomalies spanning the whole North Atlantic Ocean and is associated with above normal temperatures over the central and eastern parts of Europe, whereas the negative phase is characterized by negative SST anomalies over the North Atlantic Ocean and is associated with below normal temperatures over the central and eastern parts of Europe. Over Europe, the influence of the AMO is clearest during summer (Sutton and Dong, 2012; Ionita et al., 2012, 2017; O'Reilly et al., 2017).

In temperate climatic regions, one of the most sensitive environmental archives are ice caves (Holmlund et al., 2005; Kern and Perșoiu, 2013), i.e., rock caves hosting perennial accumulations of ice. In such caves, ice forms either by freezing of water or direct snow deposition in the entrance shafts (e.g., Mavlyudov, 2018). Several studies have shown that these deposits host a wealth of information on past climate variability. Stoffel et al. (2009), Perșoiu et al. (2017) and Sancho et al. (2018) have shown that proxies in cave ice forming during winter months record the changes in temperature and moisture sources, which are likely influenced by the dynamics of the North Atlantic Oscillation. Other studies have used pollen and plant macrofossils recovered from cave ice to reconstruct past vegetation dynamics (Feurdean et al., 2011; Leunda et al., 2019), while some works have used the accumulation rate of ice as indicators of past climatic variability (e.g., Kern et al., 2018) or atmospheric processes (Kern et al., 2009). Studies of ice caves in southern Europe have also highlighted the sensitivity of cave glaciers to summer climatic conditions (Colucci et al., 2016; Colucci and Guglielmin, 2019; Perșoiu et al., 2020). Regardless of the deposition style, the ice records the original stable isotope composition of precipitation that further reflects changes in air temperature; thus, it is an important archive of past temperature and moisture source variability (Perșoiu et al., 2011a, b). The Carpathian Mountains host ice caves (Brad et al., 2018) that preserve a large variety of geochemical information on past climate and environmental changes (Fórizs et al., 2004; Kern et al., 2004; Citterio et al., 2005; Perșoiu et al., 2017). Here, we present a reconstruction of summer climate variability and large-scale circulation drivers during the last 1000 years in east-central Europe based on the $\delta^{18} \mathrm{O}$ and $\delta^{2} \mathrm{H}$ values measured along an ice core drilled in Focul Viu Ice Cave (Western Carpathian Mountains, Romania).

\section{Site information}

Focul Viu Ice Cave (FV; $107 \mathrm{~m}$ long and $\sim 30 \mathrm{~m}$ deep) is located in the central Bihor Mountains, Romania $\left(46^{\circ} 34^{\prime} \mathrm{N}\right.$, $22^{\circ} 40^{\prime}$ E; $1165 \mathrm{~m}$ above sea level; Fig. 1a; Perșoiu and Onac, 2019). The cave has a simple morphology (Fig. 1b, c) with a small entrance that opens into the Great Hall $(68 \mathrm{~m} \times 46 \mathrm{~m})$, which, in turn, is followed by a narrow gallery (Little Hall, $20 \mathrm{~m} \times 5 \mathrm{~m}$ ). The ceiling of the Great Hall opens to the surface (Fig. 1c) which allows precipitation to reach the cave. Below the opening, covering the entire surface of the Great Hall, a layered ice block has developed, with an estimated thickness of $20 \mathrm{~m}$ and minimum volume of $30000 \mathrm{~m}^{3}$ (Orghidan et al., 1984; Brad et al., 2018). The descendent morphology of the cave and the presence of the two openings determine a specific type of air circulation (Persoiu and Onac, 2019): cold air inflow through the lower entrance and warm air outflow through the upper entrance in winter, and slow convective circulation within the cave (with no air mass exchange with the outside) during summer. As a result of this air circulation, the dynamics of air temperature inside and outside of the cave follow a similar pattern between October and April, whereas cave temperatures are stable at $0^{\circ} \mathrm{C}$ between May and September, regardless of changes outside (Perșoiu et al., 2007).

A direct consequence of the predominantly negative air temperatures in the cave is the genesis, accumulation and preservation of ice (Fig. 1b, c). During summer, infiltrating rainwater accumulates on top of the existing ice block to form a layer of water that is approximately $0-20 \mathrm{~cm}$ deep. Monitoring of air temperature in the cave has shown that air temperature drop below $0{ }^{\circ} \mathrm{C}$ outside the cave in early autumn (September), leading to cold air avalanches reaching the inner parts of the cave (Perșoiu et al., 2007). The inflow of cold air leads to the freezing of the lake water from top to bottom, forming a $1-20 \mathrm{~cm}$ thick layer of ice ("summer ice"). Although the air temperature might briefly rise above $0^{\circ} \mathrm{C}$ in autumn, temperatures inside the cave do not exceed $0^{\circ} \mathrm{C}$. Thus, the layer of ice formed on top of the lake will prevent the subsequent addition of water to the lake, thereby preserving the original isotopic composition of water reflecting that of summer precipitation. Infiltration and subsequent freezing of water during warm periods in winter result in additional layers of ice on top of the ice block ("winter ice"). However, at the onset of melting, this winter ice melts (Perşoiu et al., 2011b). The result of these processes is a multiannual, layered, ice block, consisting of annual couplets of clear ice (on top) and a sediment-rich layer beneath. Inflow of warm water in wet summers leads to rapid ablation of the ice at the top of the ice block, partly altering the annual layering. The processes of cave ice formation by water freezing and 

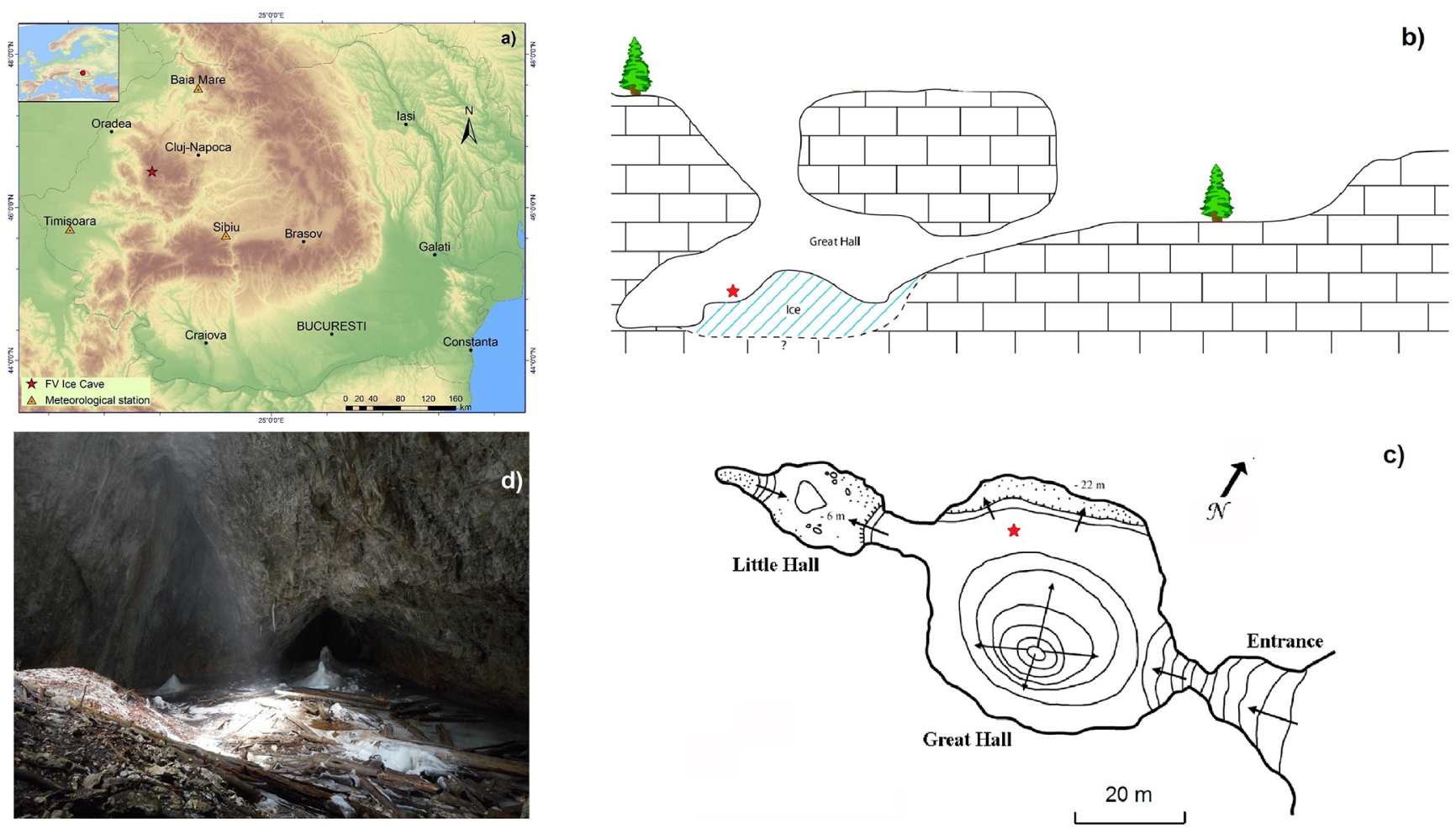

c)

Figure 1. Location of the Focul Viu Ice Cave (the red star) in Europe (a), a cross section (b) and map (c) of the cave (the red star indicates the drilling site), and (d) a general view of the Great Hall (the person in yellow on the left is standing at the drilling site). The base map in panel (a) is the digital elevation model (DEM), which was downloaded from http://geospatial.org (last access: 16 October 2020) and processed in ArcGIS by CAB. The map in panel (b) is our own work (Aurel Perșoiu), and the map in panel (c) is modified from our previous work (Brad et al., 2018).

the registration of environmental signals by various proxies (e.g., stable isotope composition of ice, pollen content) have been described from the nearby Scărișoara Ice Cave (Perșoiu and Pazdur, 2011; Feurdean et al., 2011) and, given the similarities between the two caves, are also pertinent to Focul Viu Ice Cave. The one notable difference is the timing of the onset of freezing: in Scărișoara Ice Cave, the onset of freezing is delayed until late autumn and early winter (Perșoiu et al., 2017), whereas in Focul Viu Ice Cave it starts in early autumn.

\section{Methods}

\subsection{Drilling and stable isotope analyses}

The FV ice core $(4.87 \mathrm{~m}$ long and $10 \mathrm{~cm}$ diameter) was drilled in May 2016 from the Great Hall of FV (Fig. 1d) using a modified PICO electric drill (Koci and Kuivine, 1984) manufactured by Heavy Duties S.R.L, Cluj-Napoca, Romania. A rock embedded in the ice at $4.87 \mathrm{~m}$ below the surface stopped the drilling effort, but previous work in the cave has shown that the thickness of the ice block exceeds $15 \mathrm{~m}$ (Orghidan et al., 1984; Kern et al., 2004; Persoiu and Onac, 2019). The ice core was cut into $1 \mathrm{~cm}$ long pieces (taking the annual lay- ering into account), and each piece was subsequently sealed in plastic bags, allowed to melt at room temperature, transferred to $20 \mathrm{~mL}$ HDPE (high-density poly ethylene) scintillation vials and stored at $4{ }^{\circ} \mathrm{C}$ prior to analysis.

Precipitation samples were collected monthly between March 2012 and December 2018 at Gheţar (GT, $46^{\circ} 29^{\prime} 28.45^{\prime \prime} \mathrm{N}, \quad 22^{\circ} 49^{\prime} 26.02^{\prime \prime} \mathrm{E} ; \quad 1100 \mathrm{~m}$ a.s.l.; $\sim 13 \mathrm{~km}$ southeast of the FV) using collectors built according to International Atomic Energy Agency (IAEA) specifications.

Water samples were analyzed for stable isotope composition at the Stable Isotope Laboratory, Ştefan cel Mare University (Suceava, Romania), using a Picarro L2130-i CRDS (cavity ring-down spectroscopy) analyzer connected to a high-precision vaporizing module. All samples were filtered through $0.45 \mu \mathrm{m}$ nylon membranes before analysis and were manually injected into the vaporization module multiple times until the standard deviation of the last four injections was less than 0.03 for $\delta^{18} \mathrm{O}$ and less than 0.3 for $\delta^{2} \mathrm{H}$. The average of these last four injections was normalized on the SMOW-SLAP scale using two internal standards calibrated against VSMOW2 and SLAP2 standards provided by the IAEA and further used in our interpretation. A third standard was used to check the long-term stability of the analyzer. The stable isotope values are reported using standard 
$\delta$ notation, and the precision is estimated to be better than $0.1 \%$ ofor $\delta^{18} \mathrm{O}$ and better than $0.5 \%$ for $\delta^{2} \mathrm{H}$ based on repeated measurements of an internal standard.

\subsection{Radiocarbon dating and age-depth model construction}

The wide opening to the surface in the ceiling of the Great Hall (Fig. 1c) allows for a large volume of organic matter to fall into the cave and subsequently become trapped in the ice, including large pieces of wood that tend to cut through layers of ice, with the latter possibly encompassing decades of ice accumulation. Furthermore, ice melting and water freezing processes usually result in inclined ice surfaces and slow tipping of any heavy materials sitting on top of the ice (see the position of tree trunks in Fig. 1). As a consequence, wood with an age older than that of the newly forming ice can be incorporated in the ice block, resulting in sample ages much older than the ice layers ("old wood effect"). However, the challenge of identifying such organic material contrasts with the desire for precise chronologies, which rely on a high number of data points. Thus, all possible organic samples were recovered and dated, and unreliable ages that were identified at the stage of age-depth modeling were removed. Out of 14 samples recovered from the ice core and potentially suitable for radiocarbon dating, two were not datable due to their extremely small carbon yield. Accelerator mass spectrometry (AMS) radiocarbon analyses were performed at the Institute of Physics, Silesian University of Technology, Poland (Piotrowska, 2013). All samples were precleaned with standard acid-alkali-acid treatment, dried and subjected to graphite preparation using an AGE-3 system (Ionplus, Switzerland) equipped with an Elementar vario MICRO cube elemental analyzer and automated graphitization unit (Wacker et al., 2010; Nemec et al., 2010). The ${ }^{14} \mathrm{C}$ concentrations in graphite produced from unknown samples, Oxalic Acid II standards and coal blanks of comparable carbon masses were measured by the DirectAMS laboratory, Bothell, USA (Zoppi et al., 2007). The results are reported in Table 1. The radiocarbon dates were calibrated using OxCal v4.3 (Bronk Ramsey, 2009) and the IntCal13 calibration curve (Reimer et al., 2013). The NH1 curve (Hua et al., 2013) was used for one post-bomb date.

Because organic material can fall into the cave decades to centuries before being trapped in the ice (see Fig. 1b), we have carefully screened the radiocarbon results prior to agedepth modeling with the aim of selecting the most reliable dates forming a chronological sequence. In total, four dates were selected for age-depth modeling. For the top of the ice core, a uniform age distribution from 1991 to 2016 CE was assigned, allowing for the possibility of surface ice melting. The model was constructed using the OxCal P_Sequence algorithm (Bronk Ramsey, 2008) with a variable prior $k$ parameter $(k=1, U(-2,2)$; Bronk Ramsey and Lee, 2013) and extrapolated to a depth of $4.86 \mathrm{~m}$. The agreement index of the model was $85 \%$, confirming a good statistical performance when the threshold of $60 \%$ is surpassed. The sections between the dated depths were assumed to have a constant deposition rate. The complete age-depth model is shown in Fig. 2. The mean age derived from the model was used for further analysis and is also reported in Table 1. The constructed age-depth model was compared with that of Maggi et al. (2008), plotted in green in Fig. 2, and a broad agreement was found between both chronologies. All of our rejected ages are older than those of Maggi et al. (2008), and we suspect that these were based on dating old wood that had already been in the cave for decades before being incorporated in the ice (see the "old wood effect" discussion above and Fig. 1c). Further, the same authors identified several potential markers of volcanic eruptions, and their ages agree within \pm 40 years with those of our model. Another evaluation was obtained by comparing our stable isotope record with those of Kern et al. (2004) and Forizs et al. (2004); although the latter lack a precise chronology, a simple visual correlation between the records indicates a satisfactory match. In order to avoid any circular reasoning, we decided against the use of other records, e.g., the regional temperature record, to further anchor our chronology.

\subsection{Climate data}

The sea surface temperature (SST) is extracted from version 5 of the Extended Reconstructed Sea Surface Temperature data (ERSSTv5) of Huang et al. (2018). This dataset covers the period from 1854 to present and has a spatial resolution of $2^{\circ} \times 2^{\circ}$. The AMO index used in this study was obtained from https://climexp.knmi.nl/data/iamo_ersst_ ts.dat (last access: 19 October 2020) and is also based on the ERSSTv5 dataset. Station-based meteorological data were provided by the Romanian National Meteorological Administration for three stations (Baia Mare, Sibiu and Timișoara) that have some of the longest instrumental records in Romania and bracket the location of the study site. To remove the short-term variability and retain only the multidecadal signal in our data, both the temperature time series and the SST data were smoothed with a 21-year running mean filter prior to correlation analysis.

\section{Results and discussion}

\subsection{Ice accumulation in Focul Viu Ice Cave}

The results of the radiocarbon analyses performed on organic matter recovered from the ice are shown in Table 1, and the age-depth model is displayed in Fig. 2. The maximum age of the ice is $1000 \pm 20 \mathrm{cal} \mathrm{BP}$ at $4.45 \mathrm{~m}$ below surface, based on direct dating of organic remains (Table 1) and extrapolated to $1100 \mathrm{cal} \mathrm{BP}$ at $4.86 \mathrm{~m}$ below surface

High accumulation rates were recorded between 850 and 950 CE $\left(0.39-0.41 \mathrm{~cm} \mathrm{yr}^{-1}\right)$ and between 1220 and $1970 \mathrm{CE}$ 
Table 1. Radiocarbon data from the Focul Viu Ice Cave. Agreement indices for individual samples based on the P_Sequence algorithm (Bronk Ramsey, 2008) are provided for accepted dates. Modeled ages for all dated depths are given as mean and $\sigma$ values, rounded to the nearest five.

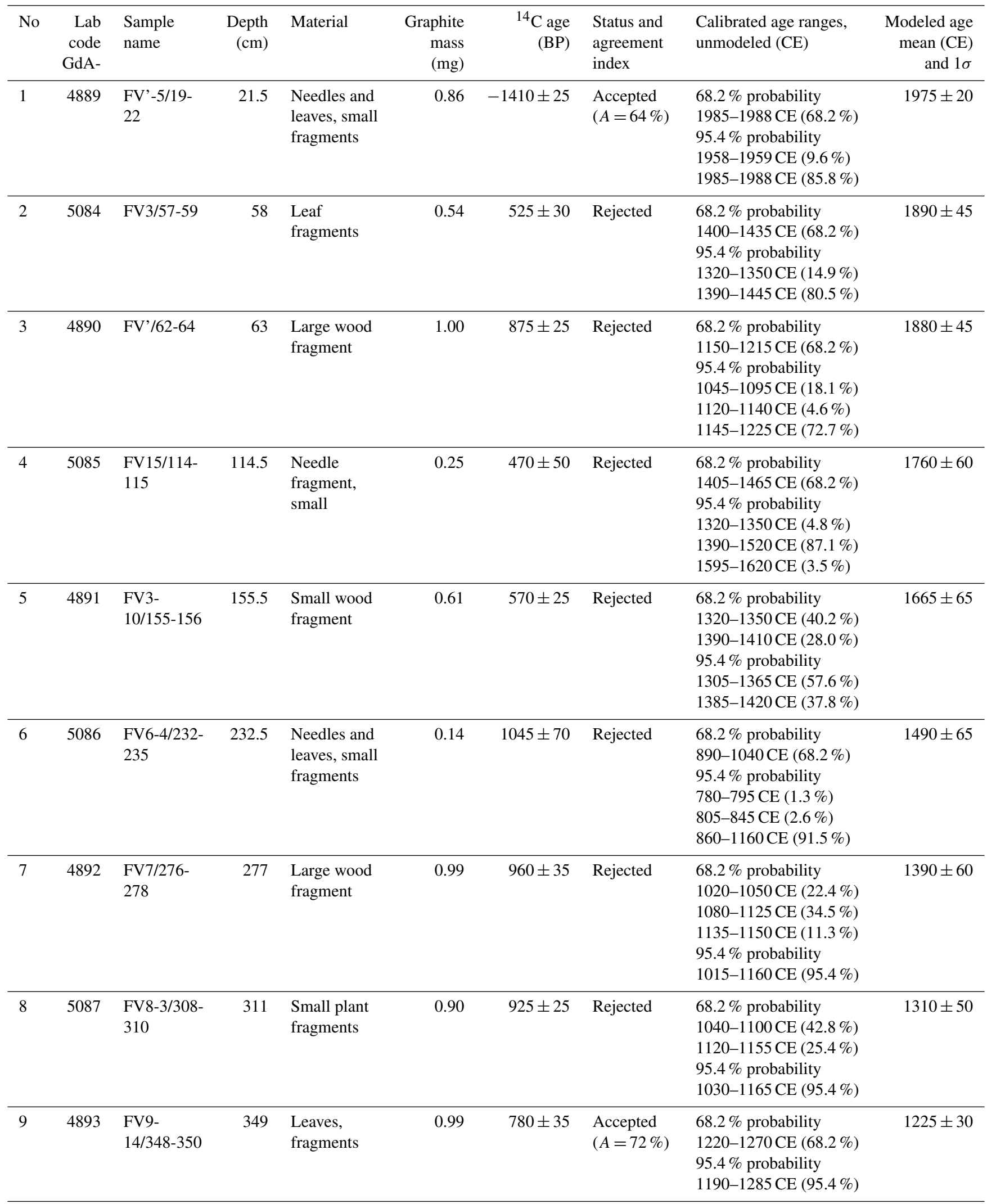


Table 1. Continued.

\begin{tabular}{|c|c|c|c|c|c|c|c|c|c|}
\hline No & $\begin{array}{r}\text { Lab } \\
\text { code } \\
\text { GdA- }\end{array}$ & $\begin{array}{l}\text { Sample } \\
\text { name }\end{array}$ & $\begin{array}{r}\text { Depth } \\
(\mathrm{cm})\end{array}$ & Material & $\begin{array}{r}\text { Graphite } \\
\text { mass } \\
(\mathrm{mg})\end{array}$ & $\begin{array}{r}{ }^{14} \mathrm{C} \text { age } \\
(\mathrm{BP})\end{array}$ & $\begin{array}{l}\text { Status and } \\
\text { agreement } \\
\text { index }\end{array}$ & $\begin{array}{l}\text { Calibrated age ranges, } \\
\text { unmodeled (CE) }\end{array}$ & $\begin{array}{r}\text { Modeled age } \\
\text { mean }(\mathrm{CE}) \\
\text { and } 1 \sigma\end{array}$ \\
\hline 10 & 5089 & $\begin{array}{l}\text { FV11- } \\
19 / 428-433\end{array}$ & 430.5 & $\begin{array}{l}\text { Small plant } \\
\text { fragments }\end{array}$ & 0.61 & $1030 \pm 20$ & $\begin{array}{l}\text { Accepted } \\
(A=97 \%)\end{array}$ & $\begin{array}{l}68.2 \% \text { probability } \\
990-1020 \text { CE }(68.2 \%) \\
95.4 \% \text { probability } \\
980-1030 \text { CE }(95.4 \%)\end{array}$ & $1000 \pm 15$ \\
\hline 11 & 5090 & $\begin{array}{l}\text { FV12- } \\
2 / 444-446\end{array}$ & 445 & $\begin{array}{l}\text { Small plant } \\
\text { fragments }\end{array}$ & 0.41 & $1140 \pm 20$ & $\begin{array}{l}\text { Accepted } \\
(A=90 \%)\end{array}$ & $\begin{array}{l}\text { 68.2\% probability } \\
885-905 \text { CE }(19.7 \%) \\
915-965 \text { CE }(48.5 \%) \\
95.4 \% \text { probability } \\
775-790 \text { CE }(3.1 \%) \\
805-820 \text { CE }(1.1 \%) \\
825-845 \text { CE }(2.3 \%) \\
860-980 \text { CE }(88.9 \%)\end{array}$ & $950 \pm 25$ \\
\hline
\end{tabular}

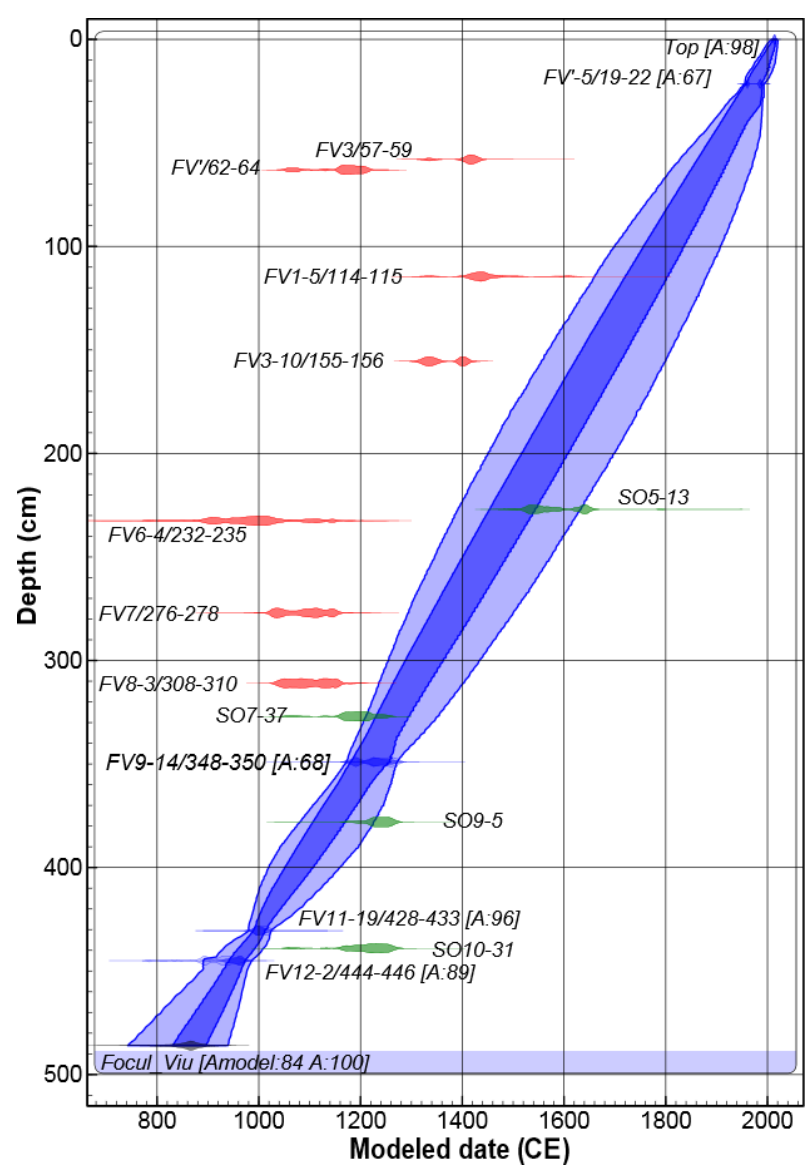

Figure 2. Age-depth model of the Focul Viu ice core. The calibrated age range of samples used in the model is indicated in blue; rejected samples are indicated in red. Samples in green are from the ice core drilled in 2004 (Maggi et al., 2008). Dark and light blue shading indicates the $95 \%$ and $68 \%$ confidence ranges of the model, respectively. $\left(0.36-0.44 \mathrm{~cm} \mathrm{yr}^{-1}\right)$. Between 950 and $1220 \mathrm{CE}$, the net accumulation rate dropped to between 0.29 and $0.34 \mathrm{~cm} \mathrm{yr}^{-1}$. The highest net accumulation rates recorded after $1970 \mathrm{CE}$ $\left(0.56 \mathrm{~cm} \mathrm{yr}^{-1}\right)$ contradict recent findings from other ice caves in the Carpathian Mountains (Kern and Perșoiu, 2013), which all register record melting. However, this value might be an artifact of the age-depth modeling (see above) as well as of the very short time span considered; thus, it is unreliable for further interpretation. The low accumulation rates spanning the MWP are similar to those recorded in the Scărișoara Ice Cave (Perșoiu et al., 2017, Bădăluţă, 2019), the Hundsalm ice cave in Austria (Spötl et al., 2014) and the ice caves in the Velebit Mountains in Croatia (Kern et al., 2018), potentially suggesting a regional signal of climatic conditions unfavorable for ice accumulation. Ice can melt as a result of either warm summers with enhanced conductive heat transfer to the cave or wet summers with rapid ablation resulting from water flowing across the top of the ice block. Subsequently, ice growth is influenced by the amount of water present at the onset of freezing, the timing of this onset and its duration. The low accumulation rates during the MWP were likely the result of enhanced melting during warm (see Sect. 4.2 below) and wet (Feurdean et al., 2015) conditions. After $1450 \mathrm{CE}$, the climate in the region was dominated by dry summers with frequent storms and cold winters (Perșoiu, 2017). These conditions led to reduced summer melting and enhanced winter growth, which are conditions favorable for net ice accumulation.

\subsection{Stable isotopes in Focul Viu cave ice - a proxy for summer air temperatures and AMO variability}

The variability of $\delta^{18} \mathrm{O}$ and $\delta^{2} \mathrm{H}$ in precipitation at Gheţar ( $\sim 13 \mathrm{~km}$ south of the cave's location and at the same altitude), assessed for the 2012-2017 CE period, follows that of temperature (Fig. 3a), with the maximum values $(-3.6 \%$ 
and $-26 \%$ for $\delta^{18} \mathrm{O}$ and $\delta^{2} \mathrm{H}$, respectively) in July and $\mathrm{Au}-$ gust and the minimum values $(-19.8 \%$ and $-140 \%$ for $\delta^{18} \mathrm{O}$ and $\delta^{2} \mathrm{H}$, respectively) in January. Similar results were found by Bojar et al. (2009) and Ersek et al. (2018) for the same region, suggesting that the ${ }^{18} \mathrm{O} /{ }^{16} \mathrm{O}$ and ${ }^{2} \mathrm{H} /{ }^{1} \mathrm{H}$ ratios in precipitation register temperature changes on a regional scale. The Local Meteoric Water Line, defined by the equation $\delta^{18} \mathrm{O}=7.4 \times \delta^{2} \mathrm{H}+6.1$ (Fig. 3b), has a slope and intercept very similar to those found by Ersek et al. (2018). Precipitation in the region is mainly delivered by weather systems carrying moisture from the Atlantic Ocean, with the Mediterranean Sea contributing moisture during autumn and winter (Nagavciuc et al., 2019b). The deuterium excess in precipitation ( $d$-excess or $d$ ), defined as $d=\delta^{2} \mathrm{H}-8 \times \delta^{18} \mathrm{O}$ (Dansgaard, 1964) allows for a clear separation of the air masses: the Atlantic Ocean ( $d$-excess close to the global average of 10; Craig, 1961) and the Mediterranean Sea $(d$ excess between 12 and 17, resulting from the high evaporative conditions in the eastern Mediterranean Sea). Similarly high values of $d$-excess have been measured in precipitation in southwestern Romania (Drăgușin et al., 2017) and in precipitation in northeastern Romania (Bădăluţă et al., 2019) and have been linked to air masses originating in the strongly evaporated Mediterranean and Black seas, respectively.

Observations on the dynamics of cave ice during the past 18 years have shown that it starts to grow in early autumn due to the freezing of water accumulated during summer. As the ceiling of the cave is opened to the outside, precipitation directly reaches the site of ice formation; thus, the stable isotope composition of precipitation is not modified in the epikarst above the cave, and the original $\delta^{18} \mathrm{O}$ and $\delta^{2} \mathrm{H}$ values of summer (June-July-August, JJA) precipitation are preserved in the cave water. However, while freezing processes in caves could alter the original $\delta^{18} \mathrm{O}\left(\right.$ and $\left.\delta^{2} \mathrm{H}\right)$ values in cave ice, several studies have shown (e.g., in the nearby Scărișoara Ice Cave; Perșoiu et al., 2011b) that the original climatic signal embedded in the stable isotope composition of cave ice is preserved and can be used as a proxy for external climate variability.

Overall, our observations of cave ice genesis and dynamics and the stable isotope monitoring data clearly indicate that summer air temperatures are registered and preserved in the ice block in the FV. In order to test the long-term stability of these connections, we have analyzed the links between the $\mathrm{FV} \delta^{18} \mathrm{O}_{\text {ice }}$ record and instrumental data from three nearby meteorological stations over the 1851-2016 CE period. On multidecadal timescales, summer air temperature changes in the region are mainly controlled by the dynamics of the Atlantic Multidecadal Oscillation (Ionita et al., 2012). Figure 4 shows the JJA air temperature at the Baia Mare (BM), Sibiu (SB) and Timișoara (TM) stations, the AMO index and the $\mathrm{FV} \delta^{18} \mathrm{O}_{\text {ice. }}$ The instrumental temperature data indicate large multidecadal variability, with a cold period between 1890 and $1920 \mathrm{CE}$, followed by a warm period between 1921 and $1960 \mathrm{CE}$, a slightly colder period between 1960 and $1980 \mathrm{CE}$
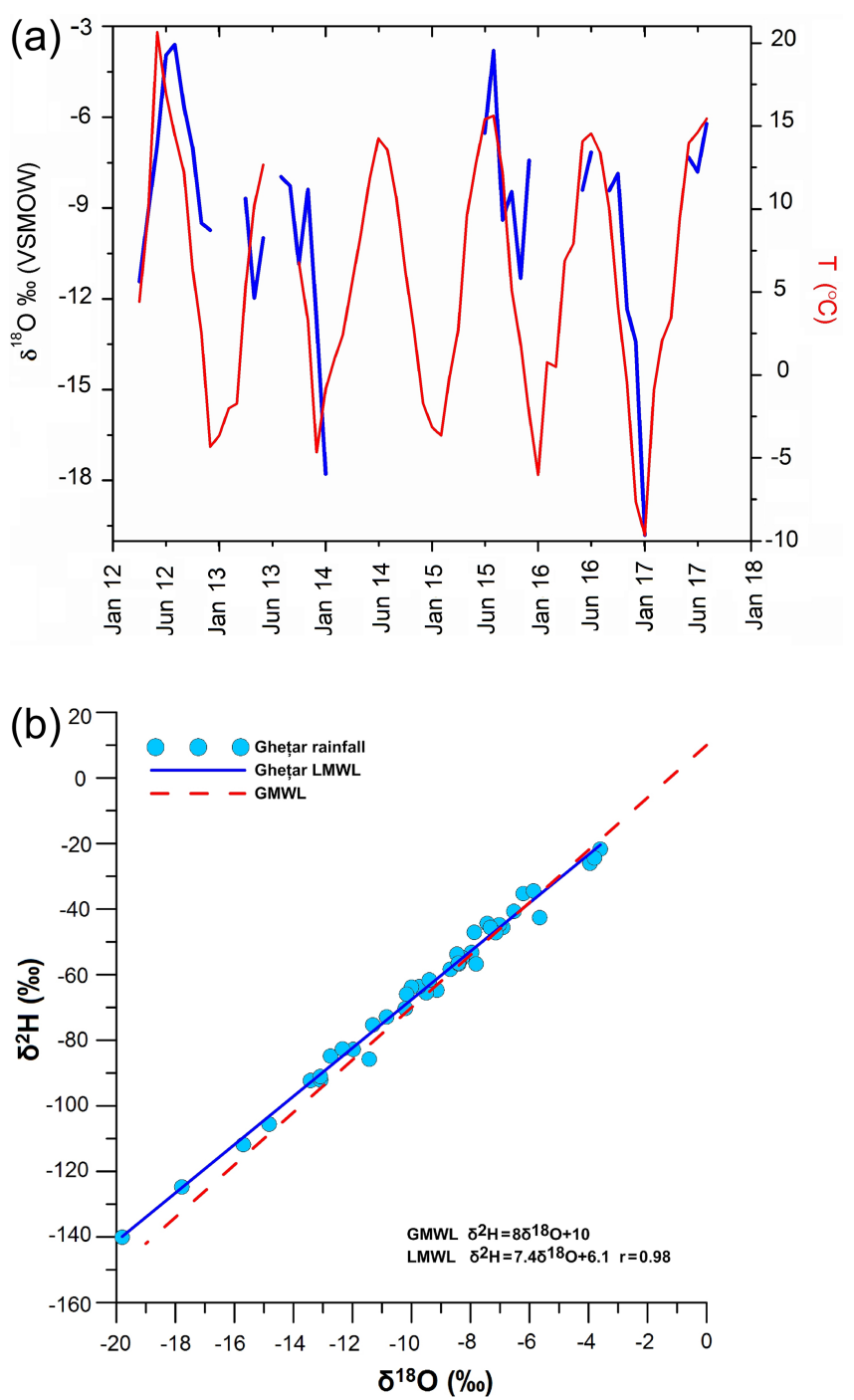

Figure 3. (a) Temporal variability of $\delta^{18} \mathrm{O}$ and $\delta^{2} \mathrm{H}$ in precipitation and air temperature at Gheţar $(10 \mathrm{~km}$ south of the Focul Viu Ice Cave and at the same altitude). (b) The Local Meteoric Water Line (LMWL) of precipitation at the same station, plotted against the Global Meteoric Water Line (GMWL).

and enhanced warming after $1980 \mathrm{CE}$, which all follow the AMO variability. The $\delta^{18} \mathrm{O}_{\text {ice }}$ values show a similar temporal evolution, with the slight offsets between the observational data and $\delta^{18} \mathrm{O}$ likely being due to the dating uncertainty (2035 years). Further, we have computed the correlation map between the summer mean air temperature at SB station (with the longest instrumental record) and the summer SST as indicator of AMO variability (Sutton and Dong, 2012). Figure 5 clearly shows that positive (negative) temperature anomalies over the analyzed region are associated with positive (negative) SST anomalies over the North Atlantic Ocean, resembling the SST anomalies associated with the positive (negative) phase of the AMO (Mesta-Nuñez and Enfield 1999; Latif et al., 2004; Knight et al., 2005). The strongest corre- 


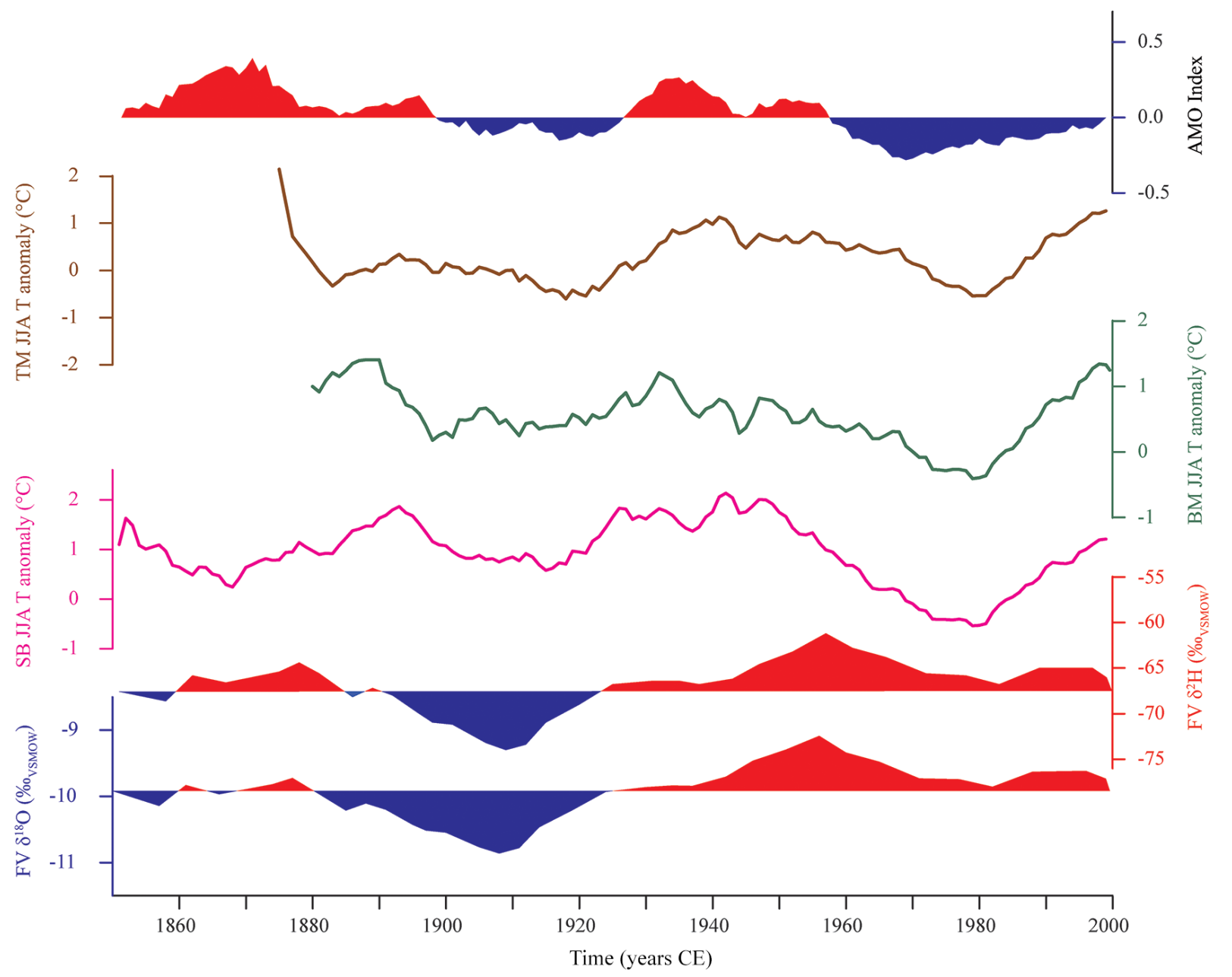

Figure 4. Temporal variability of the Atlantic Multidecadal Oscillation instrumental index; summer (JJA) air temperature (anomalies with respect to the 1961-1990 CE period) recorded at the Baia Mare (BM), Timisoara (TM) and Sibiu (SB) weather stations; and FV $\delta^{18} \mathrm{O}$ and $\delta^{2} \mathrm{H}(\% \circ)$ during the instrumental period. In the lower panels, the positive (red) and negative (blue) anomalies are shown against the 1850-2000 CE averages for the FV $\delta$ values.

lations (Fig. 5) are found between local air temperature and SSTs in the North Atlantic and the eastern Mediterranean Sea, which are the main sources of moisture feeding local precipitation (Bădăluţă et al., 2019). These results are also in agreement with the results of Della-Marta et al. (2007), who showed that summer positive temperature anomalies and heat waves over Europe are triggered, at least partially, by the phase of the AMO. A recent study of $\delta^{18} \mathrm{O}$ variability in oak tree rings in northwestern Romania $(\sim 75 \mathrm{~km}$ north of our site) also indicated the influence of the AMO on summer temperatures and drought conditions (Nagavciuc et al., 2019a). Thus, we suggest that, during summer, strongly meandering Rossby waves (Ionita et al., 2015, 2017) result in blocking conditions over central Europe that lead to the persistence of high-pressure systems and the occurrence of regional heat waves. These, in turn, favor regional recycling of moisture, resulting in positive $\delta^{18} \mathrm{O}$ anomalies in precipita- tion that are further recorded by climate proxies: stable isotopes in cave ice (this study) and tree ring parameters (width and cellulose stable isotopes) (Popa and Kern, 2009; Nagavciuc et al., 2019a). The increased contribution of recycled moisture to precipitation has been reported from several locations in central Europe, further supporting our inference (Goìmez-Hernaìndez et al., 2013; Kern et al., 2020).

Combining all of the abovementioned data, we find that, on timescales ranging from years to decades, prolonged periods of positive temperature anomalies throughout the summer months, linked to prolonged warm SSTs in the North Atlantic Ocean (and thus a positive AMO index), could be preserved by the $\delta^{18} \mathrm{O}_{\text {ice }}$ in FV.

The FV $\delta^{18} \mathrm{O}_{\text {ice }}$ and $\delta^{2} \mathrm{H}_{\text {ice }}$ records span the 850-2016 CE period (Fig. 6). Decadal- to multidecadal-scale oscillations occur over the entire record, but no discernable long-term trend has been identified. Several periods of excursions 


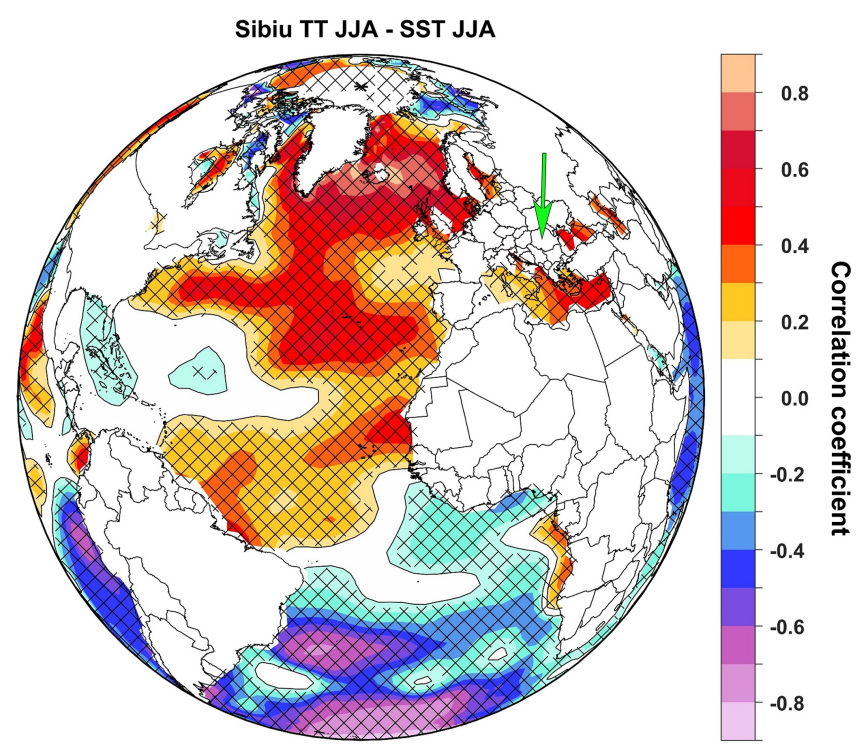

Figure 5. Spatial correlation map between sea surface temperature (SST) and average summer (JJA, June-July-August) air temperature at Sibiu ( $60 \mathrm{~km}$ south of Focul Viu Ice Cave, indicated by the green arrow) over the 1850-2011 CE period.

towards low $\delta^{18} \mathrm{O}$ values (defined as $\delta^{18} \mathrm{O}_{\text {ice }}$ below the long-term average), indicating low summer temperatures have been observed at 875-930 CE, 1050-1080 CE, 1260$1330 \mathrm{CE}, 1430-1480 \mathrm{CE}, 1520-1550 \mathrm{CE}, 1710-1750 \mathrm{CE}$, $1820-1870 \mathrm{CE}$ and $1880-1930 \mathrm{CE}$. Significant maxima in the FV $\delta^{18} \mathrm{O}_{\text {ice }}$ record occurred during 850-870 CE, 1000$1050 \mathrm{CE}, 1080-1260 \mathrm{CE}, 1350-1390 \mathrm{CE}, 1480-1520 \mathrm{CE}$, 1625-1710 CE and 1950-1970 CE (Fig. 6). Both the $\delta^{18} \mathrm{O}_{\text {ice }}$ and $\delta^{2} \mathrm{H}_{\text {ice }}$ records display a remarkable similarity throughout the entire period; thus, we have relied solely on the $\delta^{18} \mathrm{O}$ record in our discussion. We have compared the $\mathrm{FV} \delta^{18} \mathrm{O}_{\text {ice }}$ with a tree ring width-based reconstruction of summer (JJA) temperature anomalies from the Eastern Carpathian Mountains (Popa and Kern, 2009). The highest similarities between the FV ice core and summer temperature records were found for the cold periods during 1260-1330 CE, 1430 $1480 \mathrm{CE}, 1520-1550 \mathrm{CE}$ and $1820-1870 \mathrm{CE}$ and the warm periods during 1080-1260 CE, 1625-1710 CE and 19501970 CE (Fig. 6). Given the very different nature of the two archives (trees vs. cave ice), of the proxies (tree ring width and $\delta^{18} \mathrm{O}$ ) and of the chronologies (annual tree ring counting vs. ${ }^{14} \mathrm{C}$ dating with a \pm 30 -year error), the two records agree remarkably well, further supporting the hypothesis that $\delta^{18} \mathrm{O}$ and $\delta^{2} \mathrm{H}$ values in the $\mathrm{FV}$ ice core register both summer air temperature variability during the past ca. 1000 years in eastcentral Europe and, on a broader spatial scale, the variability of the AMO.

Similar to the 1850-2016 CE interval described above, the stable isotope record closely mirrors the AMO variability over the entire studied interval (Fig. 7). The relation- ship between the FV $\delta^{18} \mathrm{O}_{\text {ice }}$ and AMO records (Wang et al., 2017) is strongest between 1125 and $1525 \mathrm{CE}$ and 1750 and $2016 \mathrm{CE}$, with decadal-scale variability in the two records being synchronous. Peak-to-peak matching of the $\mathrm{FV} \delta^{18} \mathrm{O}_{\text {ice }}$ and AMO records shows that the two records correlate well within the dating uncertainty ( \pm 30 years) during the past 1000 years. However, peak-to-peak matching indicates a difference between the two records of up to $\sim 50$ years between $\sim 1600$ and $1750 \mathrm{CE}$ (Fig. 7), which is likely the result of high ( $>50$ years) uncertainty in the ice core chronology between 1525 and $1750 \mathrm{CE}$ (Fig. 7). The combined correlations between (1) $\mathrm{FV} \delta^{18} \mathrm{O}_{\text {ice }}$ and instrumental summer temperature reconstruction over the past 150 years, (2) the instrumental (this study) and proxy-based (Nagavciuc et al., 2019a) summer air temperatures and AMO variability, and (3) the FV $\delta^{18} \mathrm{O}_{\text {ice }}$ and AMO records over the past 1000 years suggest that changes in the North Atlantic are transferred, likely via atmospheric processes, towards the wider Northern Hemisphere, resulting in hemisphere-wide climatic responses to these changes.

The FV $\delta^{18} \mathrm{O}_{\text {ice }}$ record is in agreement with other summer temperature reconstructions (e.g., Buntgen et al., 2011) at both regional and hemispheric scales (Fig. 6). Further, regional summer temperature (e.g., Popa and Kern, 2009) and summer temperature-sensitive drought (Seim et al., 2012) reconstructions show warm peaks around $1320 \mathrm{CE}$, $1420 \mathrm{CE}, 1560 \mathrm{CE}$ and $1780 \mathrm{CE}$ and cold ones at around $1260 \mathrm{CE}, 1450 \mathrm{CE}$ and $1820 \mathrm{CE}$, similar to reconstructions and models at the global level (Neukom et al., 2019) and the FV temperature reconstruction (this study). Contrary to the summer season temperature reconstructions, a late-autumn through early-winter season temperature reconstruction from the nearby Scărișoara Ice Cave (Perșoiu et al., 2017) shows that the MWP was rather warm and also wet (Feurdean et al., 2011), whereas the LIA was cold and likely dry, with erratically distributed precipitation. Together, these data suggest a complex picture of climate variability in the wider Carpathian region, with much of the yearly temperature variability during the past 1000 years being attributed to the influence of winter conditions.

\section{Conclusions}

The analysis of the oxygen and hydrogen stable isotope ratios along a $\sim 5 \mathrm{~m}$ long ice core extracted from the Focul Viu Ice Cave (northwest Romania) provided an unprecedented view on the dynamics of summer air temperature and atmospheric circulation changes during the past 1000 years in east-central Europe. The comparison of ice core $\delta^{18} \mathrm{O}$ (and $\delta^{2} \mathrm{H}$ ) with instrumental data over the past 150 years indicates that the stable isotope composition of cave ice records the summer air temperatures on multidecadal timescales. Given the apparent relationship between our stable isotope record and both instrumental and proxy-derived records of the At- 


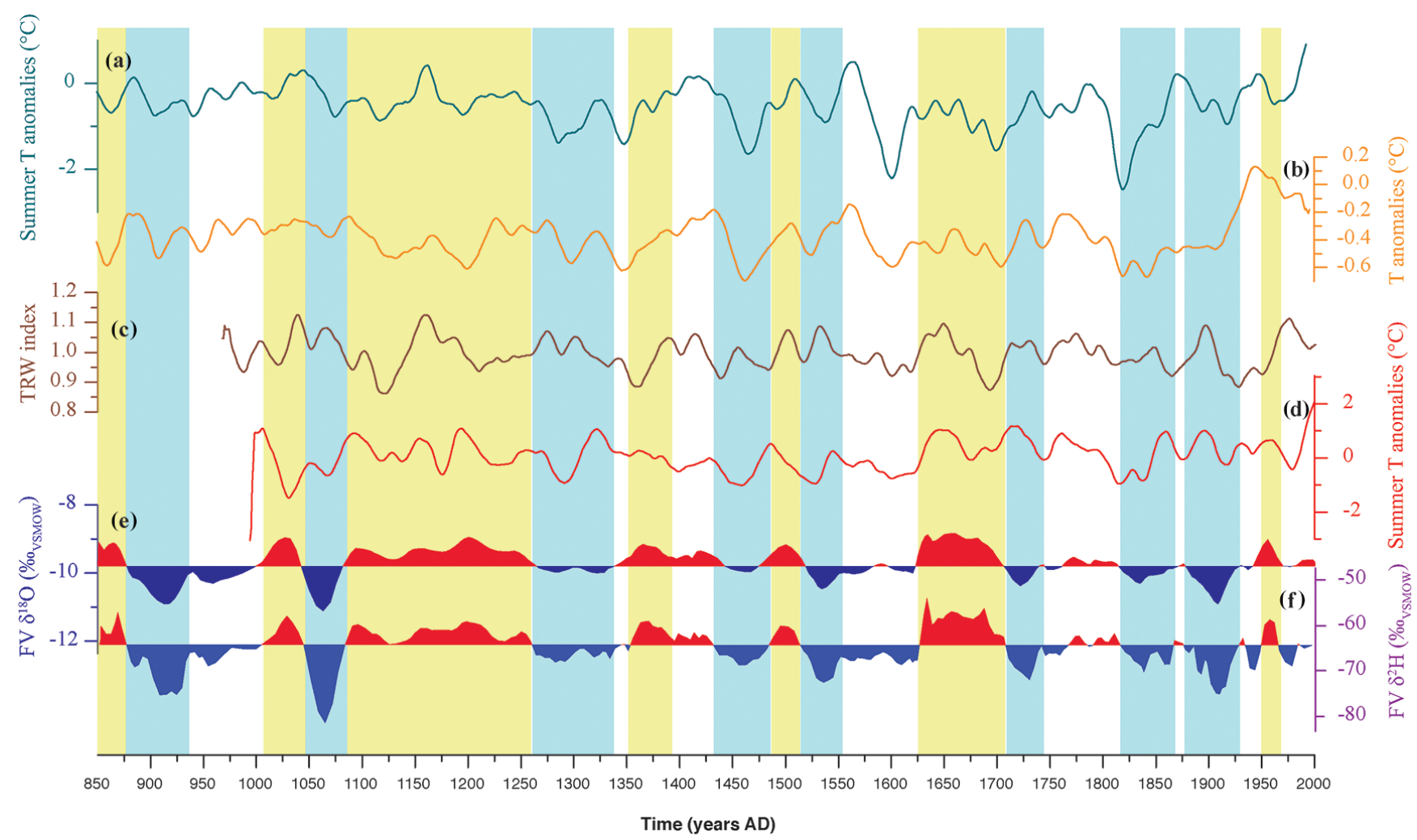

Figure 6. Summer climatic conditions recorded by $\delta^{18} \mathrm{O}$ and $\delta^{2} \mathrm{H}$ from the FV ice core (panels e and $\mathbf{f}$, bottom) and comparison with proxy indicators from the Northern Hemisphere: (a) central European summer temperature anomalies (against the 1901-2000 CE mean; Buntgen et al., 2011); (b) Northern Hemisphere air temperature anomalies (against the 1961-1990 CE mean; D'Arrigo et al., 2006), (c) tree ring width index from Albania, southeastern Europe (Seim et al., 2012); (d) summer temperature anomalies in Romania (against the 1961-1990 CE mean; Popa and Kern, 2009). Blue and yellow shaded areas indicate cold and warm periods, respectively.

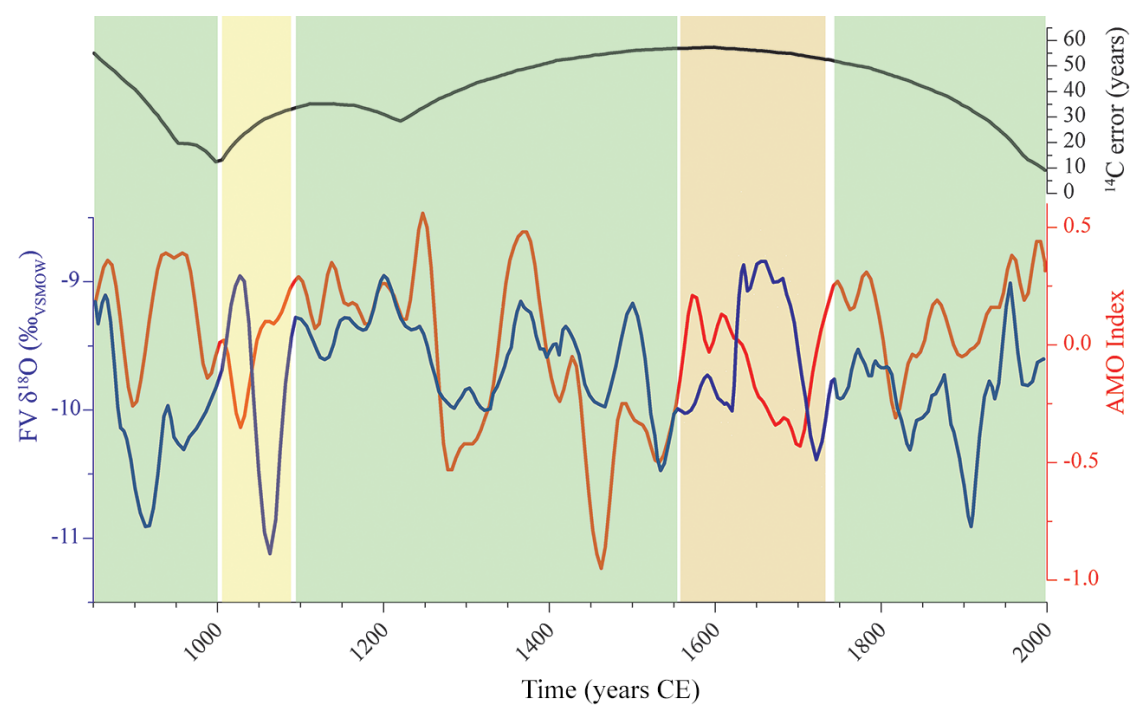

Figure 7. Temporal variability of the $\mathrm{FV} \delta{ }^{18} \mathrm{O}$ (blue), the reconstructed AMO index (Wang et al., 2017), and the ${ }^{14} \mathrm{C}$ measurement uncertainty between 850 and $2000 \mathrm{CE}$. Shading indicates the offset (in years) between the FV $\delta^{18} \mathrm{O}$ and AMO index values: green denotes less than 20 years, yellow denotes between 20 and 50 years and orange denotes above 50 years. 
lantic Multidecadal Oscillation (AMO), we further suggest that $\delta^{18} \mathrm{O}_{\text {ice }}$ in the Focul Viu Ice Cave can be used to infer past AMO variability. We subsequently hypothesize that changes in summer climatic conditions over the Northern Atlantic are transferred through atmospheric processes across the Northern Hemisphere, influencing summer temperatures across Europe. However, we emphasize that given the \pm 30 year uncertainty in the chronology, detailed studies using better constrained age models (e.g., tree-ring-based proxies) are required to test this hypothesis.

The data show little centennial-scale summer temperature variability since the onset of the Medieval Warm Period and through the Little Ice Age. Nevertheless, well-expressed minima and maxima occurred synchronously with data from other records in the region and through Europe, suggesting that the stable isotope composition from cave ice records a regional climatic signal. In contrast, winter air temperature records from the region indicate colder conditions during the LIA compared with the MWP, pointing towards a seasonally distinct climatic signal during these two periods. This suggests that forcing factors acting seasonally had a strong imprint on temperature variability, overriding long-term, global forcing.

Our results offer a potential hypothesis to be further tested by extending this and similar records back in time and also incorporating other proxy-base reconstructions to investigate the spatial extent of the influence of North Atlantic climate further east.

Data availability. The Focul Viu $\delta^{18} \mathrm{O}$ and $\delta^{2} \mathrm{H}$ data as well as the ${ }^{14} \mathrm{C}$ data and the modeled ages will be made available on the NOAA World Data Service for Paleoclimatology web page (https://www.ncdc.noaa.gov/paleo-search/, last access: 9 December 2020). The meteorological data plotted in Fig. 4 were provided by the Romanian National Meteorological Administration, except for the AMO data that were downloaded from https://climexp.knmi. nl/data/iamo_ersst_ts.dat (last access: 7 December 2020), which are created and maintained by the Royal Netherlands Meteorological Institute (https://www.knmi.nl, last access: 7 December 2020). The paleoclimate data used to plot Fig. 6a were downloaded from the NOAA World Data Service for Paleoclimatology web page (https://www.ncdc.noaa.gov/paleo-search/).

Author contributions. $\mathrm{CAB}$ and $\mathrm{AP}$ designed the project, $\mathrm{AP}$ and $\mathrm{CAB}$ collected the ice core, and $\mathrm{CAB}$ performed the stable isotope analyses. NP performed the radiocarbon analyses and constructed the age-depth model. MI analyzed the climate and large-scale circulation data. $\mathrm{CAB}$ and $\mathrm{AP}$ wrote the text, with input from MI and NP.

Competing interests. The authors declare that they have no conflict of interest.
Acknowledgements. We thank the administration of the Apuseni National Park for granting us permission to drill in the Focul Viu Ice Cave, Nicodim Pașca for collecting precipitation samples, Christian Ciubotărescu for help during the ice core drilling effort, and Vlad Murariu (Heavy Duties, Romania) for developing and constructing the drilling equipment. We thank the editor and three anonymous reviewers for comments that helped us improve the original paper, and Simon Hutchinson (University of Salford, UK) and Sara Asha Burgess for further suggestions and corrections.

Financial support. This research has been supported by the EEA Financial Mechanism 2009-2014 (project contract no. CLIMFOR18SEE), EEA Financial Mechanism 2014-2021 (project contract no. 3/2019; KARSTHIVES), and UEFISCDI Romania (grants nos. PNIII-P1-1.1-TE-2016-2210 and PNIIRU-TE-2014-4-1993). The article processing charges for this open-access publication were covered by the EXCALIBUR project of the Ştefan cel Mare University of Suceava, Romania.

Review statement. This paper was edited by Barbara Stenni and reviewed by three anonymous referees.

\section{References}

Bădăluţă C.-A: Reconstruction of air temperature during the last 1000 years based on the stable isotope analysis of ice deposits in caves from the Apuseni Mountains, Romania, PhD thesis, Stefan cel Mare University of Suceava, Suceava, Romania, 2019.

Bădăluţă, C.-A., Persoiu, A., Ionita, M., Nagavciuc, V., and Bistricean, P. I.: Stable $\mathrm{H}$ and $\mathrm{O}$ isotope-based investigation of moisture sources and their role in river and groundwater recharge in the NE Carpathian Mountains, East-Central Europe, Isot. Environ. Healt. S., 55, 161-178, https://doi.org/10.1080/10256016.2019.1588895, 2019.

Bojar, A, Ottner, F., Bojar, H. P., Grigorescu, D., and Persoiu, A.: Stable isotope and mineralogical investigations on clays from the Late Cretaceous sequences, Haţeg Basin, Romania, Appl. Clay Sci., 45, 155-163, https://doi.org/10.1016/j.clay.2009.04.005, 2009.

Brad, T., Bădăluţă, C.-A., and Persoiu, A.: Ice caves in Romania, in: Ice caves, edited by: Perşoiu, A. and Lauritzen, S.-E., Elsevier, Amsterdam, Netherlands, 511-528, https://doi.org/10.1016/B978-0-12-811739-2.00025-5, 2018.

Bronk Ramsey, C.: Bayesian analysis of radiocarbon dates, Radiocarbon, 51, 337-360, 2009.

Bronk Ramsey, C.: Deposition models for chronological records, Quaternary Sci. Rev., 27, 42-60, https://doi.org/10.1016/j.quascirev.2007.01.019, 2008.

Bronk Ramsey, C. and Lee, S.: Recent and Planned Developments of the Program OxCal, Radiocarbon, 55, 720-730, https://doi.org/10.1017/S0033822200057878, 2013.

Büntgen, U., Tegel, W., Nicolussi, K., McCormick, M., Frank, D., Trouet, V., Kaplan, J. O., Herzig, F., Heussner, K.-U., Wanner, H., Luterbacher, J., and Esper, J.: 2500 Years of European Climate Variability and Human Susceptibility, Science, 331, 578582, https://doi.org/10.1126/science.1197175, 2011. 
Citterio, M., Turri, S., Perșoiu, A., Bini, A., and Maggi, V.: Radiocarbon ages from two ice caves in the Italian Alps and the Romanian Carpathians and their significance, in: Glacier Caves and Glacial Karst in High Mountains and Polar Regions, edited by: Mavlyudov, B. R., Institute of geography of the Russian Academy of Sciences, Moscow, Russia, 87-92, 2005.

Colucci, R. R. and Guglielmin, M.: Climate change and rapid ice melt: Suggestions from abrupt permafrost degradation and ice melting in an alpine ice cave, Prog. Phys. Geog., 43, 561-573, https://doi.org/10.1177/0309133319846056, 2019.

Colucci, R. R., Fontana, D., Forte, E., Potleca, M., and Guglielmin, M.: Response of ice caves to weather extremes in the southeastern Alps, Europe, Geomorphology, 261, 1-11, https://doi.org/10.1016/j.geomorph.2016.02.017, 2016.

Coumou, D. and Rahmstorf, S.: A decade of weather extremes, Nat. Clim. Change, 2, 491-496, https://doi.org/10.1038/nclimate1452, 2012.

Craig, H.: Isotopic variations in meteoric waters, Science, 133, 1702-1703, https://doi.org/10.1126/science.133.3465.1702, 1961.

Dansgaard, W.: Stable isotope in precipitation, Tellus, 16, 436-438, https://doi.org/10.1111/j.2153-3490.1964.tb00181.x, 1964.

D'Arrigo, R., Wilson, R., and Jacoby, G.: On the long-term context for late twentieth century warming, J. Geophys. Res., 111, D03103, https://doi.org/10.1029/2005JD006352, 2006.

Della-Marta, P. M., Luterbacher, J., von Weissenfluh, H., Xoplaki, E., Brunet, M., and Wanner, H.: Summer heat waves over western Europe 1880-2003, their relationship to large scale forcings and predictability, Clim. Dynam., 29, 251-275, https://doi.org/10.1007/s00382-007-0233-1, 2007.

Drăguşin, V., Balan, S., Blamart, D., Forray, F. L., Marin, C., Mirea, I., Nagavciuc, V., Orăşeanu, I., Perşoiu, A., Tîrlă, L., Tudorache, A., and Vlaicu, M.: Transfer of environmental signals from the surface to the underground at Ascunsă Cave, Romania, Hydrol. Earth Syst. Sci., 21, 5357-5373, https://doi.org/10.5194/hess-215357-2017, 2017.

Ersek, V., Onac, B. P., and Perșoiu, A.: Kinetic processes and stable isotopes in cave dripwaters as indicators of winter severity, Hydrol. Process., 32, 2856-2862, https://doi.org/10.1002/hyp.13231, 2018.

Feurdean, A., Persoiu, A., Pazdur, A., and Onac, B. P.: Evaluating the palaeoecological potential of pollen recovered from ice in caves: a case study from Scarisoara Ice Cave, Romania, Rev. Palaeobot. Palyno., 165, 1-10, https://doi.org/10.1016/j.revpalbo.2011.01.007, 2011.

Feurdean, A., Galka, M, Kuske, E., Tanţău, I., Lamentowicz, M., Florescu, G., Liakka, J., Hutchinson, S. M., Mulch, A., and Hickler, T.: Last Millennium hydro-climate variability in Central Eastern Europe (Northern Carpathians, Romania), Holocene, 25, 1179-1192, https://doi.org/10.1177/0959683615580197, 2015.

Fórizs, I., Kern, Z., Szántó, Z., Nagy, B., Palcsu, L., and Molnár, M.: Environmental isotopes study on perennial ice in the Focul Viu Ice Cave, Bihor Mountains, Romania, Theor. App. Karst., 17, 61-69, 2004.

Gómez-Hernández, M., Drumond, A., Gimeno, L., and GarciaHerrera, R.: Variability of moisture sources in the Mediterranean region during the period 1980-2000, Water Resour. Res., 49, 6781-6794, 2013.
Haustein, K., Allen, M. R., Forster, P. M., Otto, F. E. L., Mitchell, D. M., Matthews, H. D., and Frame, D. J.: A real-time Global Warming Index, Sci. Rep., 7, 15417, https://doi.org/10.1038/s41598-017-14828-5, 2017.

Holmlund, P., Onac, B. P., Hansson, M., Holmgren, K., Morth, M., Nyman, M., and Persoiu, A.: Assessing the palaeoclimate potential of cave glaciers: the example of the Scărișoara Ice Cave (Romania), Geogr. Ann. A, 87, 193-201, https://doi.org/10.1111/j.0435-3676.2005.00252.x, 2005.

Hua, Q., Barbetti, M., and Rakowski, A. Z.: Atmospheric Radiocarbon for the Period 1950-2010, Radiocarbon, 55, 2059-2072, https://doi.org/10.2458/azu_js_rc.v55i2.16177, 2013.

Huang, B., Angel, W., Boyer, T., Cheng, L., Chepurin, G., Freeman, E., Liu, C., and Zhang, H.-M.: Evaluating SST analyses with independent ocean profile observations, J. Climate, 31, 5015-5030, https://doi.org/10.1175/JCLI-D-17-0824.1, 2018.

Ionita, M., Rimbu, N., Chelcea, S., and Patrut, S.: Multidecadal variability of summer temperature over Romania and its relation with Atlantic Multidecadal Oscillation, Theor. Appl. Climatol., 113, 305-315, https://doi.org/10.1007/s00704-012-0786-8, 2012.

Ionita M., Boroneant, C., and Chelcea, S.: Seasonal modes of dryness and wetness variability over Europe and their connections with large scale atmospheric circulation and global sea surface temperature. Clim. Dynam., 45, 2803, https://doi.org/10.1007/s00382-015-2508-2, 2015.

Ionita, M., Tallaksen, L. M., Kingston, D. G., Stagge, J. H., Laaha, G., Van Lanen, H. A. J., Scholz, P., Chelcea, S. M., and Haslinger, K.: The European 2015 drought from a climatological perspective, Hydrol. Earth Syst. Sci., 21, 1397-1419, https://doi.org/10.5194/hess-21-1397-2017, 2017.

IPCC: Global warming of $1.5^{\circ} \mathrm{C}$. An IPCC Special Report, Geneva, Switzerland, https://doi.org/10.1017/CBO9781107415324, 2018.

Jones, P. D. and Mann, M. E.: Climate over the past millennia, Rev. Geophys., 42, RG2002, https://doi.org/10.1029/2003RG000143, 2004.

Jones, P. D., Briffa, K. R., Osborn, T. J., Lough, J. M., van Ommen, T. D., Vinther, B. M., Luterbacher, J., Wahl, E. R., Zwiers, F. W., Mann, M. E., Schmidt, G. A., Ammann, C. M., Buckley, B. M., Cobb, K. M., Esper, J., Goosse, H., Graham, N., Jansen, E., Kiefer, T., Kull, C., Küttel, M., Mosley-Thompson, E., Overpeck, J. T., Riedwyl, N., Schulz, M., Tudhope, A. W., Villalba, R., Wanner, H., Wolff, E., and Xoplaki, E.: Highresolution palaeoclimatology of the last millennium: A review of current status and future prospects, The Holocene, 19, 3-49, https://doi.org/10.1177/0959683608098952, 2009.

Kaplan, A., Cane, M. A., Cushnir, Y., Clement, A. C., Blumenthal, M. B., and Rajagopala, B.: Analyses of global sea surface temperature 1856-1991, J. Geophys. Res., 103, 18567-18589, 1998.

Kern, Z. and Persoiu, A.: Cave ice - the imminent loss of untapped mid-latitude cryospheric palaeoenvironmental archives, Quaternary Sci. Rev., 67, 1-7, https://doi.org/10.1016/j.quascirev.2013.01.008, 2013.

Kern, Z., Fórizs, I., Nagy, B., Kázmér, M., Gál, A., Szánto, Z., Palcsu, L., and Molnár, M.: Late Holocene environmental changes recorded at Gheţarul de la Focul Viu, Bihor Mountains, Romania, Theor. App. Karst., 17, 51-60, 2004.

Kern, Z., Molnár, M., Svingor, É., Persoiu, A., and Nagy, B.: Highresolution, well-preserved tritium record in the ice of Bortig Ice 
Cave, Bihor Mountains, Romania, The Holocene, 19, 729-736, https://doi.org/10.1177/0959683609105296, 2009.

Kern, Z., Bočić, N., and Sipos, G.: Radiocarbon-Dated Vegetal Remains from the Cave Ice Deposits of Velebit Mountain, Croatia, Radiocarbon, 60, 1391-1402, https://doi.org/10.1017/RDC.2018.108, 2018.

Kern, Z., Hatvani, I. G., Czuppon, G., Fórizs, I., Erdélyi, D., Kanduč, T., Palcsu, L., and Vreča, P.: Isotopic "Altitude" and "Continental" Effects in Modern Precipitation across the Adriatic-Pannonian Region, Water 2020, 12, 1797 https://doi.org/10.3390/w12061797, 2020.

Kerr, R. A.: A North Atlantic Climate Pacemaker for the Centuries, Science, 288, 1984-1985, https://doi.org/10.1126/science.288.5473.1984, 2000.

Knight, J. R., Allan, R. J., Folland, C. K., Vellinga, M., and Mann, M. E.: A signature of persistent natural thermohaline circulation cycles in observed climate, Geophys. Res. Lett., 32, L20708, https://doi.org/10.1029/2005GL024233, 2005.

Knudsen, M. F., Seidenkrantz, M.-S., Jacobsen, B. H., and Kuijpers, A.: Tracking the Atlantic Multidecadal Oscillation through the last 8,000 years, Nat. Commun., 2, 178, https://doi.org/10.1038/ncomms1186, 2011.

Knudsen, M. F., Jacobsen B. H., Seidenkrantz, M.-S., and Olsen, J.: Evidence for external forcing of the Atlantic Multidecadal Oscillation since termination of the Little Ice Age, Nat. Commun., 5, 3323, https://doi.org/10.1038/ncomms4323, 2014.

Koci, B. R. and Kuivinen, K. C.: The PICO lightweight coring auger, J. Glaciol., 30, 244-245, https://doi.org/10.3189/S0022143000006018, 1984.

Latif, M., Botset, E. R. M., Esch, M., Haak, H., Hagemann, S., Jungclaus, J., Legutke, S., Marsland, S., and Mikolajewicz, U.: Reconstructing, monitoring and predicting multidecadal-scale changes in the North Atlantic thermohaline circulation with sea surface temperature, J. Climate, 17, 1605-1614, https://doi.org/10.1175/15200442(2004)017<1605:RMAPMC>2.0.CO;2, 2004.

Leunda, M., González-Sampériz, P., Gil-Romera, G., Bartolomé, M., Belmonte-Ribas, Á., Gómez-García, D., Kaltenrieder, P., Rubiales, J. M., Schwörer, C., Tinner, W., Morales-Molino, C., and Sancho, C.: Ice cave reveals environmental forcing of long-term Pyrenean tree line dynamics, J. Ecol., 107, 814-828, https://doi.org/10.1111/1365-2745.13077, 2019.

Ljungqvist, F. C., Seim, A., Krusic, P. J., González-Rouco, J. F., Werner, J. P., Cook, E. R., Zorita, E., Luterbacher, J., Xoplaki, E., Destouni, G., García-Bustamante, E., Aguilar, C. A. M., Seftigen, K., Wang, J., Gagen, M. H., Esper, J., Solomina, O., Fleitmann, D., and Büntgen, U.: European warm-season temperature and hydroclimate since 850 CE, Environ. Res. Lett., 14, 084015, https://doi.org/10.1088/1748-9326/ab2c7e, 2019.

Maggi, V., Turri, S., Bini, A., and Udisti, R.: 2500 Years of history in Focul Viu Ice Cave, Romania, in: Proceedings of the 3rd International Workshop on Ice Caves, 12-17 May 2008, Perm, Russia, 11-15, 2008.

Mann, M. E., Zhang, Z., Rutherford, S., Bradley, R., Hughes, M. K., Shindell, D., Ammann, C., Faluvegi, G., and Ni, F.: Global signatures and dynamical origins of the Little Ice Age and Medieval Climate Anomaly, Science, 326, 1256-1260, https://doi.org/10.1126/science.1177303, 2009.
Mavlyudov, B. R.: Ice genesis and types of ice caves, in: Ice caves, edited by: Perșoiu, A. and Lauritzen, S. E., Elsevier, Amsterdam, the Netherlands, 34-68, https://doi.org/10.1016/B978-012-811739-2.00032-2, 2018.

Mesta-Nuñez, A. M. and Enfield, D. B.: Rotated global modes of non-ENSO sea surface temperature variability, J. Climate, 12, 2734-2746, https://doi.org/10.1175/15200442(1999)012<2734:RGMONE>2.0.CO;2, 1999.

Moberg, A., Sonechkin, D. M., Holmgren, K., Datsenko, N. M., and Karlén, W.: Highly variable Northern Hemisphere temperatures reconstructed from low- and high-resolution proxy data, Nature, 433, 613-617, https://doi.org/10.1038/nature03265, 2005.

Nagavciuc, V., Ionita, M., Persoiu, A., Popa, I., Loader, N. J., and McCarroll, D.: Stable oxygen isotopes in Romanian oak tree rings record summer droughts and associated large-scale circulation patterns over Europe, Clim. Dynam., 52, 6557-6568, https://doi.org/10.1007/s00382-018-4530-7, 2019a.

Nagavciuc, V., Bădăluţă, C.-A., and Ionita, M.: Tracing the Relationship between Precipitation and River Water in the Northern Carpathians Base on the Evaluation of Water Isotope Data, Geosciences, 9, 198, https://doi.org/10.3390/geosciences9050198, $2019 b$.

Nemec, M., Wacker, L., and Gäggeler, H. W.: Optimization of the Graphitization Process at AGE-1, Radiocarbon, 52, 1380-1393, 2010.

Neukom, R., Steiger, N., Gómez-Navarro, J. J., Wang, J., and Werner, J. P.: No evidence for globally coherent warm and cold periods over the preindustrial Common Era, Nature, 571, 550 554, https://doi.org/10.1038/s41586-019-1401-2, 2019.

O'Reilly, C. H., Woollings, T., and Zanna, L.: The Dynamical Influence of the Atlantic Multidecadal Oscillation on Continental Climate, J. Climate, 30, 7213-7230, https://doi.org/10.1175/JCLID-16-0345.1, 2017.

Orghidan, T., Negrea, Ş., Racoviţă, G., and Lascu, C.: Peșteri din România: ghid turistic, Sport-Turism, Bucharest, Romania, 1984.

PAGES 2K Consortium: Consistent multidecadal variability in global temperature reconstructions and simulations over the Common Era, Nat. Geosci., 12, 643-649, https://doi.org/10.1038/s41561-019-0400-0, 2019.

Persoiu, A.: Climate evolution during the Late Glacial and the Holocene, in: Landform dynamics and evolution in Romania, edited by: Rădoane, M. and Vespremeanu-Stroe, A., Springer, Berlin and Heidelberg, Germany, 57-66, https://doi.org/10.1007/978-3-319-32589-7_3, 2017.

Persoiu, A. and Onac, B. P.: Ice caves in Romania, in: Cave and Karst Systems of Romania, edited by: Ponta, G. M. L. and Onac, B. P., Springer, Berlin and Heidelberg, Germany, 455-465, https://doi.org/10.1007/978-3-319-90747-5_52, 2019.

Perşoiu, A. and Pazdur, A.: Ice genesis and its long-term mass balance and dynamics in Scărişoara Ice Cave, Romania, The Cryosphere, 5, 45-53, https://doi.org/10.5194/tc-5-45-2011, 2011.

Perșoiu, A., Feier, I., Citterio, M., Turri, S., and Maggi, V.: Preliminary data on air temperature in Focul Viu Ice Cave (Bihor Mts., Romania), in: Proceedings of the 2nd International Workshop on Ice Cave, 8-12 May 2006, Demänovská Dolina, Slovak Republic, 62-64, 2007. 
Persoiu, A., Onac, B. P., and Perșoiu, I.: The interplay between air temperature and ice dynamics in Scărișoara Ice Cave, Romania, Acta Carsologica, 40, 445-456, https://doi.org/10.3986/ac.v40i3.4, 2011a.

Persoiu, A., Onac, B. P., Wynn, J. G., Bojar, A.-V., and Holmgren, K.: Stable isotope behavior during cave ice formation by water freezing in Scărișoara Ice Cave, Romania, J. Geophys. Res., 116, D02111, https://doi.org/10.1029/2010JD014477, 2011b.

Persoiu, A, Onac, B. P., Wynn, J. G., Blaauw, M., Ionita, M., and Hansson, M.: Holocene winter climate variability in Central and Eastern Europe, Sci. Rep., 7, 1196, https://doi.org/10.1038/s41598-017-01397-w, 2017.

Perşoiu, A., Ionita, M., and Weiss, H.: Atmospheric blocking induced by the strengthened Siberian High led to drying in west Asia during the 4.2 ka BP event - a hypothesis, Clim. Past, 15, 781-793, https://doi.org/10.5194/cp-15-781-2019, 2019.

Persoiu, A., Buzjak, N., Onaca, A., Pennos, C., Sotiriadis, Y., Ionita, M., Zachariadis, S., Styllas, M., Kosutnik, J., Hegyi, A., and Butorac, V.: Unprecedented loss of surface and cave ice in SE Europe related to record summer rains in 2019, The Cryosphere Discuss., https://doi.org/10.5194/tc-2020-287, in review, 2020.

Piotrowska, N.: Status report of AMS sample preparation laboratory at GADAM Centre, Gliwice, Poland, Nucl. Instrum. Meth. B, 294, 176-181, 2013.

Popa, I. and Kern, Z.: Long-Term Summer Temperature Reconstruction Inferred from Tree-ring Records from the Eastern Carpathians, Clim. Dynam., 32, 1107-1117, https://doi.org/10.1007/s00382-008-0439-x, 2009.

Reimer, P. J., Bard, E., Bayliss, A., Beck, J. W., Blackwell, P. G., Bronk Ramsey, C., Grootes, P. M., Guilderson, T. P., Haflidason, H., Hajdas, I., Hatte, C., Heaton, T. J., Hoffmann, D. L., Hogg, A. G., Hughen, K. A., Kaiser, K. F., Kromer, B., Manning, S. W., Niu, M., Reimer, R. W., Richards, D. A., Scott, E. M., Southon, J. R., Staff, R. A., Turney, C. S. M., and van der Plicht J.: IntCal13 and Marine13 Radiocarbon Age Calibration Curves 0-50,000 Years cal BP, Radiocarbon, 55, 1869-1887, https://doi.org/10.2458/azu_js_rc.55.16947, 2013.
Sancho, C., Belmonte, Á., Bartolomé, M., Moreno, A., Leunda, M., and López-Martínez, J.: Middle-to-late Holocene palaeoenvironmental reconstruction from the A294 ice-cave record (Central Pyrenees, northern Spain), Earth Planet. Sci. Lett., 484, 135-144, https://doi.org/10.1016/j.eps1.2017.12.027, 2018.

Schlesinger, M. and Ramankutty, N.: An oscillation in the global climate system of period 65-70 years, Nature 367, 723-726, https://doi.org/10.1038/367723a0, 1994.

Seim, A., Büntgen, U., Fonti, P., Haska, H., Herzig, F., Tegel, W., Trouet, V., and Treydte, K.: Climate sensitivity of a millenniumlong pine chronology from Albania, Clim. Res., 51, 217-228, https://doi.org/10.3354/cr01076, 2012.

Spötl, C., Reimer, P. J., and Luetscher, M.: Long-term mass balance of perennial firn and ice in an Alpine cave (Austria): Constraints from radiocarbon-dated wood fragments, The Holocene, 24, 165-175, https://doi.org/10.1177/0959683613515729, 2014.

Stoffel, M., Luetscher, M., Bollschweiler, M., and Schlatter, F.: Evidence of NAO control on subsurface ice accumulation in a $1200 \mathrm{yr}$. old cave-ice sequence, St. Livres ice cave, Switzerland, Quaternary Res., 72, 16-26, https://doi.org/10.1016/j.yqres.2009.03.002, 2009.

Sutton, R. T. and Dong, B.: Atlantic Ocean influence on a shift in European climate in the 1990s, Nat. Geosci., 5, 788-792, https://doi.org/10.1038/ngeo1595, 2012.

Wacker, L., Nemec, M., and Bourquin, J.: A revolutionary graphitisation system: Fully automated, compact and simple, Nucl. Instrum. Meth. B, 268, 931-934, 2010.

Wang, J., Yang, B., Ljungqvist, F. C., Luterbacher, J., Osborn, T. J., Briffa, K. R., and Zorita, E.: Internal and external forcing of multidecadal Atlantic climate variability over the past 1,200 years, Nat. Geosci., 10, 512-517, https://doi.org/10.1038/ngeo2962, 2017.

Zoppi, U., Crye, J., Song, Q., and Arjomand A.: Performance evaluation of the new AMS system at Accium BioSciences, Radiocarbon, 49, 173-182, 2007. 